\title{
A Reliability Verification of Screening Time Prediction Reporting of 'Cine-Hangeul'
}

\author{
Byoung-Won Jeon ${ }^{1 *}$
}

\begin{abstract}
Cine-Hangeul is a program that can predict the running time of a movie based on the screenplay before production. This paper seeks to verify the prediction reporting function of Cine-Hangeul, which is the standard Korean screenplay format. Moreover, this paper presents a method to increase the accuracy of the Cine-Hangeul reporting function. The objective of this paper is to offer a correction method based on scientific evidence because the current Cine-Hangeul reporting function has many errors. The verification process for five scenarios and movies confirmed that the default setting value of Cine- Hangeul's screening time prediction reporting was many errors. Cine-Hangeul analyzes the amount of textual information to predict the time of the scene and the time of the dialogue and helps predict the total time of the movie. Therefore, if a certain amount of text information is not available, the accuracy is unreliable. The current Cine-Hangeul prediction report confirms that the efficiency is high when the scenario volume is about 90 to 100 pages. As a result, prediction of screening time by Cine-Hangeul, a Korean scenario standard format program, confirmed the verification that it could secure the same level of reliability as the actual screening time by correcting the reporting settings. This verification also affirms that when applying about 50 percent of the basic set of screening time reporting, it is almost identical to the screening time.
\end{abstract}

Key Words: Standard Screenplay Format, Cine-Hangul, Screening Time, Cine-Hangul Screening Time Reporting Correction Value .

\section{INTRODUCTION}

In order to start the movie production, the process of classifying and organizing the completed scenario according to the standard format into elements is the first. This process is called scenario break down. In this process, each page of the scenario divided into eight equal parts, and the one part means the screening time of 7.5 secondsdivided by $1 / 8$ minute. Except for very complicated or difficult action scenes or special cases such as blue screen shooting, it usually takes 1 to 2 hours to shoot the first portion. This stage is the first process to convert the estimated time it will take for an all shot of a scenario written in 1 minute per page. "In the case of a typical movie, it takes 2 to 3 pages a day, and you can guess that a scenario of 100 pages takes 30-50 days" [1]. "It is a critical process to estimate the budget of movie production. We get accurate shooting

schedules, and budget plans, a realistic and economic breakdown must make through thorough scenario analysis [2]. Then, the elements of the scenarios should arrange, and the screen time scale should be accurate. Therefore, standardization of scenario format is an important issue [3].
Cine-Hangeul, a program that provides a standard format for Korean movie scenarios, has a reporting function that can predict movie screening times. The prediction of screening time in the standard scenario format can increase the efficiency of filmmaking, and increase the competitiveness of film production by reducing unnecessary pre-production and expenditure in film production. Therefore, the accuracy of CineHangeul's prediction of screening time can have a great impact on enhancing the efficiency of Korean filmmaking. In 2007, the development of programs to streamline the Korean film production system began in earnest. The KOFIC(Korean Film Council) and the KFPA(Korean Film Producers Association) would develop the CINEERP(Enterprise Resource Planning) system in two years [3]. The CINE-ERP system is a program for establishing standardized models throughout filmmaking management, including budget and scenarios needed for filmmaking, and for streamlining production. It consists of filming schedule management, salary management, budget management, investment company, and production company claim settlement management, staff and work management, and a screenplay editor. Production using

Manuscript received May 30, 2020; Revised June 20, 2020; Accepted June 21, 2020. (ID No. JMIS-20M05-016)

Corresponding Author (*): Byoung-Won Jeon, (47340) Eomgwang-ro 176, Busanjin-gu, Busan, Korea, Cinema \& Transmedia Institute, Dong-eui University, +82-51-890-2737, cciinnee@deu.ac.kr

${ }^{1}$ Cinema \& Transmedia Institute, Dong-eui University, 176, Busanjin-gu, Busan, Korea, cciinnee@ deu.ac.kr 
the CINE-ERP system became active for a while in the early stages of development [4]. However, it soon became an incomplete attempt due to passive use by production companies.

Among the functions of CINE-ERP, the 'scenario editor' was the first standard screenplay authoring tool of Korea. The 'scenario editor,' along with the standard form of the scenario, could automatically classify the text information by scene, place, person, and time through a keyword search of scenario. The function enabled the director and production departments to save working hours in scenario analysis and pre-production. However, scenario editors were not used actively either [5].

Cine-Hangeul is a screenplay writing program jointly developed by the 'KFPA(Korea Film Producers Association)'and 'Hangeul and Computer' based on the 'Scenario editor' of the CINE-ERP system. The functional composition of Cine-Hangeul is generally the same as the scenario editor. However, the scenario editor's automatic classification function has been enhanced as a reporting function in Cine-Hangeul. The specific particularity of the Cine-Hangeul reporting function is the screening time prediction function. This function predicts the screening time during production by analyzing the text information when entering the scene. Cine-Hangeul reporting predicts the screening time of the scene, the screening time of the dialogue, the screening time of each scene, and the total screening time. This paper tries to verify the accuracy of the total screening time reporting of Cine-Hangeul. The fact that the total screening time can be predicted only by the scenario can maximize efficiency through the objectification of time arrangement at the film production site and scene composition when creating the scenario. However, this is based on trust in its accuracy. Therefore, the Cine Hangeul screening time reporting credibility must be verified to secure the basis for utilizing this function [6]. It must be verified for the popularization of Cine-Hangeul programs to increase the efficiency of filmmaking.

\section{DESIGN OF VERIFICATION FOR CINE- HANGEUL SCREENING TIME REPORTING}

\subsection{Factors affecting screening time}

In Hollywood, where the movie production system is the most advanced, the standard format of scenario writing tools is designed to predict a one-minute screening time per page. Hollywood uses a variety of software, including
'Final Draft', 'Movie Magic Screenwriter', and 'Movie Outline' and 'Montage'. In the most basic terms, a screenplay is a 90-120 page document written in Courier $12 \mathrm{pt}$ font on 'A4', bright white three-hole punched paper. One formatted script page in Courier font equals roughly one minute of screen time. That's why the average page count of a screenplay should come in between 90 and 120 pages. Comedies tend to be on the shorter side (90 pages, or $1 \frac{1}{2}$ hours) while Dramas run longer (120 pages, or 2 hours) [7]. Because of the standard format of the scenario utilized, it is possible to predict the screening time, and this prediction system maximizes the efficiency of filmmaking.

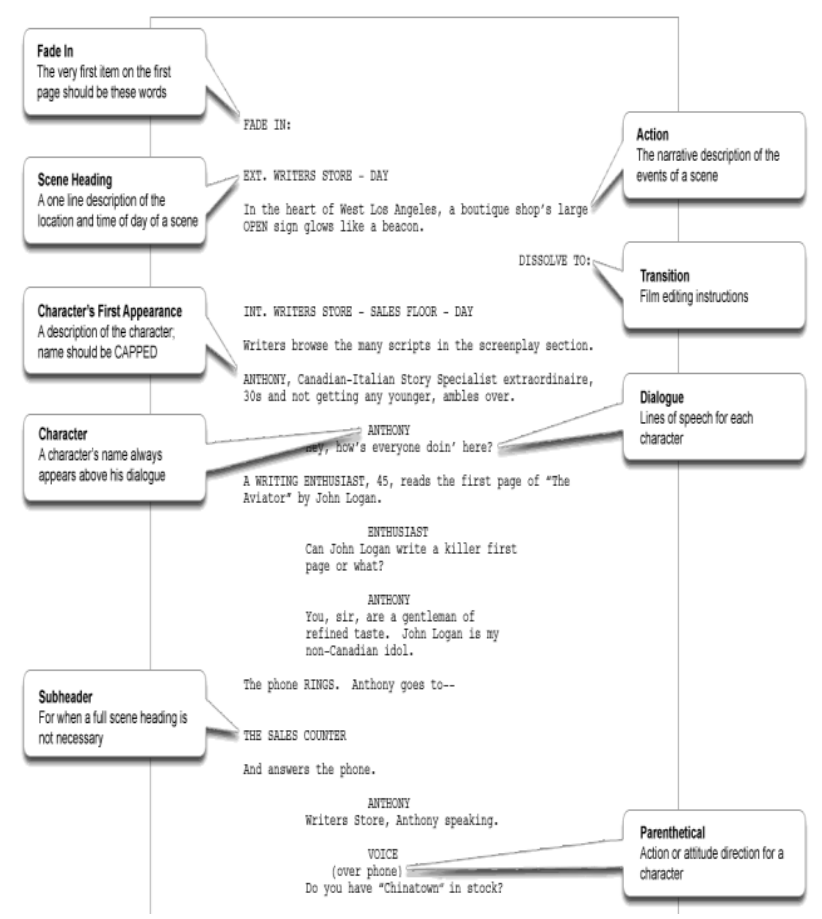

Fig. 1. Example of Hollywood scenario standard format [8].

Currently, in Korea, one scene is generally predicted to be screened in one minute. It is not a scientific and objective way. Because Korea does not currently use a standardized scenario format, the amount of text information and classification of the scenario make it impossible to predict the running time of the video image. The current production system, in which the screening time can be checked only after editing, is a clear indication of the inefficiency of the production environment. It is not uncommon for a movie with 120 minutes of running time to exceed 240 minutes.

Kim Young-cheol explains the necessity of predicting the running time as follows. "It is not easy to make accurate screening time calculations in making a movie. Prediction of the running time is a sense naturally obtained from many productions and directing 
experiences, but in fact, it revealed when the filming performed $20-30 \%$. Nevertheless, when the shooting is in progress, most of the schedule is pushed to the plan, and the filming proceeds despite knowing that the amount will be significantly over. During the editing process, as the general theater screening time is organized(edited) within about 100 minutes, the film proceeds in the wrong direction, and the relationship between the character and the character becomes a strange relationship. Eventually, the narrative's probability broken, and the story is unexplained. This situation may be due to some of the scenarios truncated during the editing process. For this reason, when it completed as a movie, I had many experiences of becoming a movie that the audience could not understand. The film should be written logically according to the running time of the final film. How do you make accurate screening time calculations during this process [8].

If we can predict the screening time by standardizing the scenario format, we will have the opportunity to preexamine the filming of unnecessary scenes or leaks of unnecessary production costs, thereby securing efficiency and competitiveness of the movie production system.

Various factors affect the screening time of a movie. First, it is the amount of screenplay during the scenario creation phase. It depends on how detailed the description is in the scenario, and the number of pages depends on the number of the characters' lines of dialogue. It is related to the writing style of screenwriters. Secondly, it is the director's style of directing during the filming stage. The length of each scene depends on the director's style of production of the same scene in the scenario. Third, it is the difference in editing style in the editing stage. The difference in the way each scene is connected will result in a difference in the total screening time.

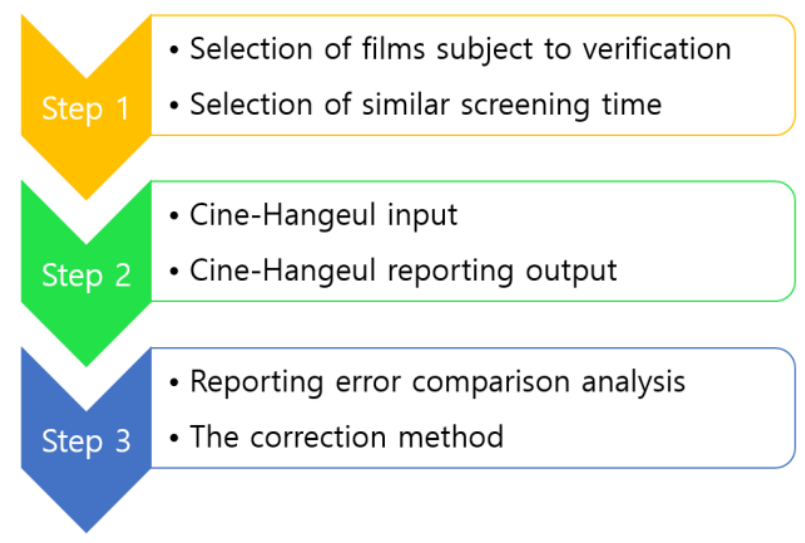

Fig. 2. Design of verification for Cine-Hangeul Screening Time.

\subsection{Verification targets and methods}

To verify Cine-Hangeul's screening time reporting, films with similar screening times were selected and compared to minimize variables in the verification process and methods.

The criteria for selection for verification are as follows.

First, we verify movies with a screening time of 119 minutes to 120 minutes. As a result, the final predicted times will be verified for films with similar screening times. Information on the screening time of the selected films were based on information from the Korean Film Database (KMDB). Five films were selected for verification. Directors Bong Joon-ho's <The Host>, Ryu Seung-wan's <The Unjust>, Lee Jun-Ik's <King And Clown>, Park Chan-wook's <Sympathy For Mr. Vengeance $>$, and $\langle$ Oldboy $>$ are the works to be verified. These five scenarios entered in Cine-Hangeul are unified into the standard format of the scenario.

Second, we will compare and verify the works of various directors. We want to compare and verify films by directors with different directing styles to see how much variables depending on the directing style affect the prediction of screening time. Four director's works with different directing styles were selected. Besides, two works by the same director select to grasp the influence of the style of the director. The targets are Park Chanwook's $<$ Sympathy For Mr. Vengeance $>$, and $<$ Oldboy $>$. It is because they can judge that they produced in a similar style in Park Chan-wook's 'revenge trilogy'. Run the scenario reporting in the same standard format.

Third, we compare and verify films that have similar screening times but differ significantly in the number of screenplay pages. All five films have a screening time of 119 to 120 minutes, for which the number of pages of screenplay for <The Host> and <The Unjust> is the same at 93 pages. There are 110 pages for $<$ The King and the Clown>, 65 pages for <Oldboy>, and 38 pages for $<$ Sympathy For Mr. Vengeance>. Compare and analyze the screening time reporting values.

\section{ANALYSIS OF CINE-HANGEUL SCREENING TIME REPORTING}

\subsection{Screening time prediction reporting result}

The results of the screening time report obtained after entering the five scenarios to be verified into CineHangeul are as follows.

Looking at the results of the Cine-Hangul screening time prediction reporting shown in the above table (Table 1), <Sympathy For Mr. Vengeance> was predicted to be 31 minutes and 44 seconds shorter than the screening time. 
$<$ Oldboy> was predicted to be 61 minutes 45 seconds longer than the actual time, <The Host> was 120 minutes 24 seconds overpredicted, <King And Clown> was 124 minutes 46 seconds too long, and <The Unjust> was 87 minutes 24 seconds longer. As a result of verifying the prediction report of screening time of Cine-Hangul, it can be seen that the screening time and the error range of the actual screening are too divergent.

Table 1. Cine-Hangeul screening time reporting results.

\begin{tabular}{|c|c|c|c|c|c|c|c|c|}
\hline Title & Director & $\begin{array}{l}\text { Number } \\
\text { of } \\
\text { scenario } \\
\text { pages }\end{array}$ & $\begin{array}{c}\text { Number } \\
\text { of } \\
\text { scenes }\end{array}$ & $\begin{array}{l}\text { Actual } \\
\text { Screening } \\
\text { time } \\
\text { (1) }\end{array}$ & $\begin{array}{l}\text { Scenes } \\
\text { Screening } \\
\text { time } \\
\text { prediction }\end{array}$ & $\begin{array}{l}\text { Dialogue } \\
\text { Screening } \\
\text { time } \\
\text { prediction }\end{array}$ & $\begin{array}{l}\text { Total } \\
\text { Screening } \\
\text { time } \\
\text { orediction } \\
\text { (2) }\end{array}$ & $\begin{array}{l}\text { Error } \\
\text { value } \\
(2)-(1)\end{array}$ \\
\hline $\begin{array}{l}\text { Sympathy } \\
\text { For Mr. } \\
\text { Vengeance }\end{array}$ & $\begin{array}{l}\text { Park } \\
\text { Charnook }\end{array}$ & $37-2 / 8$ & 126 & $120 \mathrm{~min}$ & $\begin{array}{r}68 \mathrm{~min} \\
50 \mathrm{sec}\end{array}$ & $\begin{array}{l}19 \mathrm{~min} \\
26 \mathrm{sec}\end{array}$ & $\begin{array}{l}88 \mathrm{~min} \\
16 \mathrm{sec}\end{array}$ & $\begin{array}{l}-31 \mathrm{~min} \\
44 \mathrm{sec}\end{array}$ \\
\hline Qldopoy & $\begin{array}{l}\text { Park } \\
\text { Chamook }\end{array}$ & $64-6 / 8$ & 112 & $.120 \mathrm{~min}$ & $\begin{array}{c}129 \mathrm{~min} \\
19 \mathrm{sec}\end{array}$ & $\begin{array}{l}52 \mathrm{~min} \\
56 \mathrm{sec}\end{array}$ & $\begin{array}{l}182 \mathrm{~min} \\
15 \mathrm{sec}\end{array}$ & $\begin{array}{c}+61 \text { min } \\
45 \mathrm{sec}\end{array}$ \\
\hline The Host & $\begin{array}{l}\text { Bong } \\
\text { Joanho }\end{array}$ & $92-4 / 8$ & 101 & $11.9 \mathrm{~min}$ & $\begin{array}{c}196 \mathrm{mln} \\
15 \mathrm{sec}\end{array}$ & $\begin{array}{l}44 \mathrm{~min} \\
21 \mathrm{sec}\end{array}$ & $\begin{array}{l}240 \mathrm{~min} \\
36 \mathrm{sec}\end{array}$ & $\begin{array}{c}+120 \mathrm{~min} \\
24 \mathrm{sec}\end{array}$ \\
\hline $\begin{array}{l}\text { The King } \\
\text { And } \\
\text { The Jown }\end{array}$ & Lee lunik & $117-0 / 8$ & 83 & $119 \mathrm{~min}$ & $\begin{array}{l}1117 \mathrm{~min} \\
30 \mathrm{sec}\end{array}$ & $\begin{array}{l}66 \mathrm{~min} \\
44 \mathrm{sec}\end{array}$ & $\begin{array}{l}244 \mathrm{~min} \\
14 \mathrm{sec}\end{array}$ & $\begin{array}{c}+124 \mathrm{~min} \\
46 \mathrm{sec}\end{array}$ \\
\hline $\begin{array}{l}\text { The } \\
\text { Uniust }\end{array}$ & $\begin{array}{l}\text { Ryu } \\
\text { Seungwan }\end{array}$ & $92-7 / 8$ & 111 & $119 \mathrm{~min}$ & $\begin{array}{l}156 \mathrm{~min} \\
26 \mathrm{sec}\end{array}$ & $\begin{array}{l}88 \mathrm{~min} \\
20 \mathrm{sec}\end{array}$ & $\begin{array}{l}244 \mathrm{~min} \\
46 \mathrm{sec}\end{array}$ & $\begin{array}{c}+87 \mathrm{~min} \\
24 \mathrm{sec}\end{array}$ \\
\hline
\end{tabular}

The usual method of calculating one-minute per scene would have predicted running times of 6 minutes longer for <Sympathy For Mr. Vengeance>, and 8 minutes shorter for <Oldboy>, 18 minutes for <The Host>, 36 minutes for <The King and the Clown>, and eight minutes shorter for <The Unjust> comparing actual running time to the prediction. It is more accurate than the prediction made through the scenario standard format. Then we conclude that it is impossible to predict screening time with a standardized scenario format. However, the correction of the default setting for reporting can increase the accuracy of the reported time.

\subsection{Correction of Cine-Hangeul Reporting Settings}

Let's apply only $50 \%$ of the Cine-Hangeul reporting default setting. Looking at the result of applying $50 \%$ of the default setting value of Cine Hangul screening time reporting shown in the above table (Table 2), <Sympathy For Mr. Vengeance > is 75 minutes and 52 seconds shorter than the actual screening time and 〈Oldboy> is 28 minutes and 52 seconds shorter. <The Host> appears 1 minute 18 seconds, <The King and the Clown> 3 minutes 07 seconds, and <The Unjust> 5 minutes 24 seconds longer.

Table 2. Cine-Hangeul screening time reporting result (50\%).

\begin{tabular}{|c|c|c|c|c|c|c|c|}
\hline Title & $\begin{array}{c}\text { Number } \\
\text { of } \\
\text { scenario } \\
\text { pages }\end{array}$ & $\begin{array}{l}\text { Actual } \\
\text { Screening } \\
\text { time } \\
\text { (1) }\end{array}$ & $\begin{array}{l}\text { Scenes } \\
\text { Screening } \\
\text { time } \\
\text { prediction }\end{array}$ & $\begin{array}{c}\text { Dialogue } \\
\text { Screening } \\
\text { time } \\
\text { prediction }\end{array}$ & $\begin{array}{c}\text { Total } \\
\text { Screening } \\
\text { time } \\
\text { prediction } \\
\text { (2) }\end{array}$ & $\begin{array}{l}\text { Error } \\
\text { value } \\
(2)-(1)\end{array}$ & Reliability \\
\hline $\begin{array}{l}\text { Sympatty } \\
\text { For Mr. } \\
\text { vengeance }\end{array}$ & $37-2 / 8$ & $120 \mathrm{~min}$ & $\begin{array}{l}34 \mathrm{~min} \\
25 \mathrm{sec}\end{array}$ & $\begin{array}{l}9 \mathrm{~min} \\
43 \mathrm{sec}\end{array}$ & $\begin{array}{l}44 \mathrm{~min} \\
08 \mathrm{sec}\end{array}$ & $\begin{array}{l}-75 \mathrm{~min} \\
52 \mathrm{sec}\end{array}$ & $36.7 \%$ \\
\hline Oldboy & $64 \cdot 6 / 8$ & $120 \mathrm{~min}$ & $\begin{array}{l}64 \mathrm{~min} \\
40 \mathrm{sec}\end{array}$ & $\begin{array}{l}26 \mathrm{~min} \\
28 \mathrm{sec}\end{array}$ & $\begin{array}{l}91 \mathrm{~min} \\
08 \mathrm{sec}\end{array}$ & $\begin{array}{l}-28 \mathrm{~min} \\
52 \mathrm{sec}\end{array}$ & $75.9 \%$ \\
\hline The Host & $92-4 / 8$ & $119 \mathrm{~min}$ & $\begin{array}{l}98 \mathrm{mln} \\
08 \mathrm{sec}\end{array}$ & $\begin{array}{l}22 \mathrm{~min} \\
10 \mathrm{sec}\end{array}$ & $\begin{array}{c}120 \mathrm{~min} \\
18 \mathrm{sec}\end{array}$ & $\begin{array}{l}+1 \text { min } \\
18 \mathrm{sec}\end{array}$ & $99.0 \%$ \\
\hline $\begin{array}{l}\text { The King } \\
\text { And } \\
\text { The Clown }\end{array}$ & $117-0 / 8$ & $119 \mathrm{~min}$ & $\begin{array}{l}58 \mathrm{~min} \\
45 \mathrm{sec}\end{array}$ & $\begin{array}{l}33 \mathrm{~min} \\
22 \mathrm{sec}\end{array}$ & $\begin{array}{c}122 \mathrm{~min} \\
07 \mathrm{sec}\end{array}$ & $\begin{array}{c}+3 \mathrm{~min} \\
07 \mathrm{sec}\end{array}$ & $97.4 \%$ \\
\hline The Uniust & $92-7 / 8$ & $119 \mathrm{~min}$ & $\begin{array}{l}78 \mathrm{~min} \\
13 \mathrm{sec}\end{array}$ & $\begin{array}{l}44 \min \\
10 \mathrm{sec}\end{array}$ & $\begin{array}{l}122 \mathrm{~min} \\
23 \mathrm{sec}\end{array}$ & $\begin{array}{l}+5 \min \\
24 \mathrm{sec}\end{array}$ & $97.2 \%$ \\
\hline
\end{tabular}

* $\mathrm{R}=100-\{($ AST-TSTP)/100 $\}$

R: Reliability

AST: Actual Screening Time

TSTP: Total Screening Time Prediction

<Sympathy For Mr. Vengeance> (37 pages) and $<$ Oldboy> (67 pages), which have a lower number of screenplay pages, have a large margin of error from the actual screening time. In comparison, <The Host> with more than 90 pages of screenplay, <The Unjust> (93 page), and <The King and the Clown> (117 pages) show less time and error than the actual screening time. We see from these results that if the amount of screenplay is larger, the accuracy of the prediction is higher.

It can also be seen that the larger the error between the scenario quantity and the number of scenes, the greater the predicted error in screening time, and the smaller the difference, the smaller the error range.

Looking at the reliability results, it is analyzed to be <Sympathy For Mr. Vengeance>: 36.7\%, <Oldboy>: $75.9 \%$, <The Host $>$ : 99.0\%, <The King and the Clown>: $97.4 \%$, <The Unjust $>$ : $97.2 \%$. 


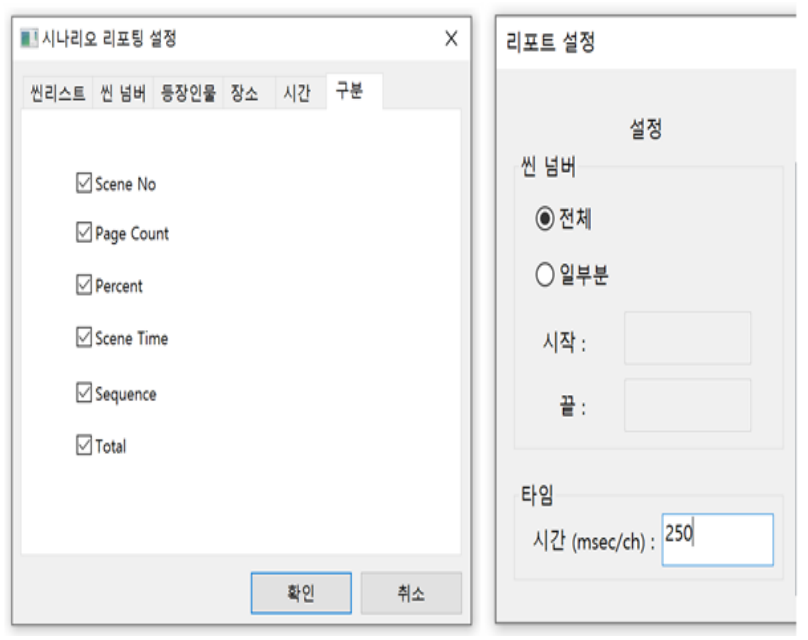

Fig. 3. Cine-Hangeul Screening Time Reporting, Result of default setting.

Cine-Hangeul screening time prediction reporting is a system that predicts the total amount of video information as a result of text information. The prediction result of Cine-Hangeul screening time nearly matches the actual screening time when $50 \%$ of the set value is applied when the whole scenario is more than 90 pages. Currently, the default value $(\mathrm{msec} / \mathrm{ch})$ of Cine-Hangul screening time reporting prediction is set to 250 . If we apply 125 , which is $50 \%$ of the default setting, we can increase its reliability.

\subsection{Reverse estimate correction values}

Table 3. Cine-Hangeul Screening Time Reporting, Result by inverse estimation.

\begin{tabular}{|c|c|c|c|c|c|c|c|}
\hline Title & Director & $\begin{array}{l}\text { Actual } \\
\text { Screening } \\
\text { time } \\
\text { (1) }\end{array}$ & $\begin{array}{l}\text { Total } \\
\text { Screening } \\
\text { time } \\
\text { prediction } \\
\text { (2) }\end{array}$ & $\begin{array}{c}\text { Correction } \\
\text { Setting } \\
\text { value } \\
\text { (mesc/ch) }\end{array}$ & $\begin{array}{l}\text { Ratio } \\
\text { against } \\
\text { default } \\
\text { setting }\end{array}$ & $\begin{array}{l}\text { Error } \\
\text { value } \\
(1)-(2)\end{array}$ & Reliability \\
\hline $\begin{array}{l}\text { Sympathy } \\
\text { For Mr. } \\
\text { vengeance }\end{array}$ & $\begin{array}{l}\text { Park } \\
\text { Chen-wook }\end{array}$ & $120 \mathrm{~min}$ & $\begin{array}{l}120 \mathrm{~min} \\
20 \mathrm{sec}\end{array}$ & 342 & $136.8 \%$ & $+20 \mathrm{sec}$ & $99.8 \%$ \\
\hline Oldboy & $\begin{array}{l}\text { Park } \\
\text { Oren-yook. }\end{array}$ & $120 \mathrm{~min}$ & $\begin{array}{l}120 \mathrm{~min} \\
10 \mathrm{sec}\end{array}$ & 165 & $66.0 \%$ & $+10 \mathrm{sec}$ & $99.9 \%$ \\
\hline The Host & $\begin{array}{l}\text { Bong } \\
\text { bon-ho }\end{array}$ & $119 \mathrm{~min}$ & $\begin{array}{l}1.19 \mathrm{~min} \\
17 \mathrm{sec}\end{array}$ & 124 & $49.6 \%$ & $+17 \sec$ & $99.9 \%$ \\
\hline $\begin{array}{l}\text { The King } \\
\text { And } \\
\text { The Clown }\end{array}$ & Lee Junik & $11.9 \mathrm{~min}$ & $\begin{array}{l}1.19 \mathrm{~min} \\
06 \mathrm{sec}\end{array}$ & 122 & $48.8 \%$ & $+06 \mathrm{sec}$ & $99.9 \%$ \\
\hline The Uniust & $\begin{array}{l}\text { RVu } \\
\text { Seung-wan }\end{array}$ & $1.19 \mathrm{~min}$ & $\begin{array}{l}119 \mathrm{~min} \\
13 \mathrm{sec}\end{array}$ & 122 & $48.8 \%$ & $+13 \mathrm{sec}$ & $99.8 \%$ \\
\hline
\end{tabular}

We can deduce through the reporting verification results above to derive the predicted reporting setting value for Cine-Hangeul screening time according to the scenario amount. The following is the result of an inverse estimation of the most accurate set value for the actual screening time.

Looking at the result of inverse estimation of the CineHangul screening time reporting setting value shown in Table 3, <Sympathy For Mr. Vengeance> shows an error of 20 seconds when the setting value is $342,136.8 \%$ of the default setting value; <Oldboy> has an error of 10 seconds when the setting value is $165,66.0 \%$ of the default setting value; <The Host> has an error of 17 seconds when the setting value is 124 , and $49.6 \%$ of the default setting value; <King And Clown> has the setting value 122, an error of 6 seconds or $48.8 \%$ compared to the default setting; <The Unjust> has an error of 13 seconds when the setting is $122,48.8 \%$ compared to the default setting.

\section{CONCLUSION}

In this paper, the credibility was verified by comparing the screening time of the already-completed film with the Cine-Hangeul reporting result. The reliability of the predicted screening time of Cine-Hangeul can be made $99.8 \%$ for <Sympathy For Mr. Vengeance>, <The Unjust $>$, $99.9 \%$ for $\langle$ Oldboy>, <The Host $\rangle$, and $\langle$ The King and the Clown $>$. The average verified reliability for the five films is $99.86 \%$.

As a result, prediction of screening time by CineHangeul, a Korean scenario standard format program, confirmed the verification that it could secure the same level of reliability as the actual screening time by correcting the reporting settings.

Cine-Hangeul is a program that can predict the running time of a movie based on the screenplay before production. If we set the screening time that the director expects first, and derive the appropriate setting value depending on that screening time, we can get the results of the prediction of the screening time for each scene and the screening time for the dialogue. We can enhance the efficiency of filmmaking by utilizing the screening time for each scene and the screening time for each dialogue.

Correcting the reporting settings is essential in order to use Cine-Hangeul's prediction of screening time for filmmaking stages. A follow-up study on the verification of the reliability of screening time by scene is also needed based on the results of the correction of these settings. The reliability of screening time by scene can bring changes to the scenario creation process and the film production process. Furthermore, Cine-Hangeul can be used for scripting and production of all video contents as well as movies. Therefore, it is essential to study the accuracy of 
the screening time for each scene in the future.

\section{Acknowledgements}

This work was supported by the Ministry of Education of the Republic of Korea and the National Research Foundation of Korea (NRF) (NRF-2017S1A5B8059186).

\section{REFERENCES}

[1] J. Park. "Master Book of Movie Production", Press of BooK \& Road, P.66, 2004.

[2] J. Kim, "A Study on the Producer's role in the Filmmaking", Journal of the Moving Image Technology Association of Korea, vol. 1, no.52002, pp. 55-56, 2003.

[3] Y. Yoon, "The study on the necessity of script format standardization and its possibility in Korean movie industry," Journal of the Moving Image Technology Association of Korea, vol. 1, no. 292019, pp. 19-34, 2019.

[4] KOFIC, "Trends and Prospects of Korean Cinema", Dec. 2007.

[5] S. Lee. "Research on the efficiency of film production through CINE-ERP”, Thesis of Doctoral, Dongkuk University, pp. 19-22, 2011.

[6] M. Moreno, K. Tuxford, "How to Write a Screenplay: Script Writing Example \& Screenwriting Tips", Writersstore.,

https://www.writersstore.com/how-to-write-a-screenplay-a-guide-to scriptwriting/ (25. May. 2020.)

[7] ] M. Moreno, K. Tuxford, "How to Write a Screenplay: Script Writing Example \& Screenwriting Tips", Writersstore.,

https://www.writersstore.com/how-to-write-a-screenplay-a-guide-toscriptwriting/ (25. May. 2020.)

[8] Y. Kim, "Pending issues and problems about Scenario editor image education by image education institutions including universities-focusing on Scenario editor", Journal of the Moving Image Technology Association of Korea, vol. 1, no. 302019, pp. 114-132, Jun. 2019.
Authors

Byoung-won Jeon received his BPA degree in the Department of Playwriting and Drama from Seoul Institute of The Arts, Korea, in 1993 and MA degrees in the Department of Art from Paris University 1, France, in 2006. He received a Ph.D. degree in the Department of Humanities for planning cinema \& video at Jeonbuk National University in 2013, His research interests include 'Storytelling,' 'Film Policy,' '4th Industrial Revolution and film Environment.' 